\title{
Assessment of Thalassemic Children Knowledge about Thalassemia and Iron Chelation Therapy
}

\section{Donia El-Said Zaghamir, Dr. Rehab Hanea El-Kazaz „Dr. Amal Ahmed Khalil, Dr . Mohammed Mohammed Ahmed Elmazahy}

Assist lecturer of pediatric nursing,Faculty of Nursing, Port Said University, Assistant Professor of Pediatric Nursing Department, Faculty of Nursing, Port Said University, Professor of Pediatric nursing Faculty of Nursing, Port said University, Professor of Pediatric Medicine Faculty of Medicine Elazhar University,.

\begin{abstract}
Background: Thalassemia is a major inherited public health problem in the Mediterranean area. Aim of this study was to assess children knowledge about thalassemia and iron chelation therapy. Subjects and methods: A descriptive research design was used. A convenient sample was used; it includes 50 thalassemic children on chelation therapy, and their family caregiver.. This study conducted at the pediatrics outpatient department at the Health Insurance Agency Hospital in Damietta city. Tools Two tools used for data collection. An interview questionnaire form to collect data about socio-demographic characteristics for studied children and their caregivers, assessment of knowledge related thalassemia and iron chelation therapy sheet. Results: revealed that, only $26 \%$ of children had satisfactory knowledge related thalassemia, and only $12.0 \%, 26 \%$ of the studied children had total satisfactory knowledge related to management of thalassemia and desferal respectively. Conclusion, the study concluded that there is an improvement in the children's knowledge. The study recommended developing frequent educational training programs for children with thalassemia about chelation therapy through updated posters, booklets and brochures and a repeat of this research on a large sample and in various places in Egypt for improving children's knowledge and practice
\end{abstract}

Keywords: chelation therapy, knowledge, thalassemia. 


\section{INTRODUCTION}

Thalassemia is a major inherited public health problem in Mediterranean people; and it is defined as a group of inherited autosomal recessive disorders, characterized by an impaired of hemoglobin chain synthesis (Carman \& Kyle, 2015). Thalassemia results from an alteration in the rate of globin chain production. A decrease in the rate of production of a certain globin chains $(\alpha, \beta, ¥, 8)$ impedes hemoglobin synthesis and creates an imbalance with the other normally produced globin chains (Yaish, 2013).

Beta thalassemia major (also called Cooley's anemia) is a common health problem in Egypt, it has been estimated that 1000 children with B thalassemia are born annually for every 1.5 million live birth with an estimated carrier rate of 9-10\% (El-Beshlawy, 2008; Zorac et al., 2013), and is associated with a life threatening form of anemia that requires regular blood transfusion and ongoing medical care. There is no cure for thalassemia, so the goal of treatment is to normalize the $\mathrm{Hb}$ and HCT of the child, thus alleviating the symptoms of severe anemia. This is accomplished via a regular schedule of blood transfusions. (Cooley Anemia Foundation, 2009; Kline, 2010).

The therapeutic management of Thalassemia major includes regular RBC transfusions, iron chelation and management of secondary complications of iron overloads. Repeated blood transfusions in children with Thalassemia result in a buildup of excess iron in the body, causing iron overloads or hemosiderosis. The excess iron is stored in the cells of many organs and tissues, particularly in the liver and heart; iron is toxic to the tissues and organs, and may cause organ failure and death (Linker, 2010).

Repeated blood transfusions in children with thalassemia result in a buildup of excess iron in the body, causing iron overload or hemosiderosis, the excess iron is stored in the cells of many organs and tissues, particularly in the liver and heart. Iron is toxic to the tissues and organs and cause organ failure and death. (Linker, 2009).

A chelation therapy is given to reduce the amount of stored iron, and is a drug used to either prevent or reverse the toxic effects of a heavy metal or to accelerate the elimination of the metal from the body. Deferral (deferoxamine) has to be administrated subcutaneous over $8-12$ hours $5-7$ days per week through a painful and difficult process. (McCance \& Grey, 2010). 
Nursing management for the child with beta thalassemia major is centered on family teaching and family support, as well as actual treatment of the anemia. The nurse is responsible for administering the blood transfusions and observing for transfusion reactions. Because beta thalassemia major eventually results in death, the child and caregivers may need assistance in coping with the disease, its treatment and its eventual outcome. (Zorac et al., 2013).

The objectives of nursing care are to promote compliance to the transfusion and chelation therapy, assist the child in coping with the anxiety-provoking treatments and the effects of the illness, foster the child and family adjustment to achronic illness and observe for complications of multiple blood transfusions (Wilson \& Hockenberry, 2011).

\section{AIM OF STUDY:}

Assessment of knowledge of children having thalassemia undergoing chelation therapy.

\section{SUBJECTS AND METHOD:}

\section{(I) TECHNICAL DESIGN}

\section{Research design:}

A descriptive research design was used in the current study.

\section{Setting:}

This study conducted at the pediatrics outpatient department at the Health Insurance Agency Hospital in Damietta city

\section{Sampling size:}

The sample size was calculated to determine an expected rate of 50\% improvement in children's knowledge and QoL. Using the Epi-Info 6.04 statistical software package sample size estimator for the difference between two proportions at $95 \%$ level of confidence and $80 \%$ study power, and an expected dropout rate of approximately $5 \%$, the required sample size turned to be 50 children with their caregivers 


\section{Sampling technique:}

A consecutive sampling technique was utilized to recruit children and their caregivers in the study sample according to the eligibility criteria such as(Age 8-18 years,Confirmed diagnosis of B-thalassemia major, Receiving chelation therapy in the study setting ...........)

\section{TOOLS FOR DATA COLLECTION:}

Tool (I): Structured interview questionnaire:

This tool developed by the researcher based on review of related literature. It was designed in Arabic language to suit understanding of the study subjects to assess knowledge of children having thalassemia undergoing chelation therapy

The tool consisted of the following parts:

Part I: Socio-demographic data sheet: This part was for collecting data about child's demographic characteristics as age, gender, birth order, level of education, as well as any school problems related to illness. It also involved questions about parents and family characteristics such as age, level of education, occupation, family type, residence, income, crowding index, etc

Part II:This covered the medical history of the child. It involved questions about the age at diagnosis, duration of illness, family history, symptoms, treatment followed including blood transfusion and desferal use details and related complications, investigations done, compliance with treatment and follow-up, as well as the problems getting medical care.

Part III: This was intended to assess child's knowledge at various phases of the intervention. It covered three areas of knowledge as follows.

- Thalassemia: 6 questions covering its nature, prevalence, causes, symptoms, complications, and causes of complications.

- Treatment: 11 questions covering types, benefits and problems of blood transfusion, iron accumulation, high iron food, food increasing iron absorption, drugs ridding body of excess iron and their benefits, use of these drugs and their side effects, and needed investigations

- Desferal: 9 questions covering its importance, weekly dose, side effects and their management such as inflammation of the abdomen, abdominal abscess, disturbed vision/ hearing, and allergy, when to stop and the symptoms that need stopping. 
- Scoring: For each question, a correct response was scored 1 and the incorrect zero. For each area of knowledge, the scores of the items were summed-up and the total divided by the number of the items, giving a mean score for the part. These scores were converted into percent scores. Knowledge was considered satisfactory if the percent score was $50 \%$ or more and unsatisfactory if less than $50 \%$.

\section{(II) OPERATIONAL DESIGN:}

\section{Preparatory phase}

During this phase, the researcher reviewed local and international related literature using internet search, textbooks, and scientific journals. This helped in increasing acquaintance with the study topic and in the preparation of the data collection tools.

\section{A. Content tool Validity:}

Once the tools were prepared in their preliminary forms, they were presented to a panel of seven experts in nursing and medical pediatrics and oncology for face and content validation. The tools were then adjusted based upon the recommendations of these experts... Changes were done according to the experts opinions. This phase was carried out in a period of one month before starting data collection.

\section{B. Reliability:}

Reliability of tools was done using Cronbach Alpha Test. The tools of the study were applied to 5 children. Reliability coefficient for tool I was 0.8 and for tool II was 0.7.

\section{Pilot study:}

A pilot study was undertaken after the development and validation of the study tools and before starting the data collection phase. It was carried out on a sample of about $10 \%$ of the main study sample. The purposes of the pilot study were to test the applicability, clarity, and feasibility of the study tools, and it served to estimate the time needed to complete the forms. It also helped to find out any obstacles and problems that might interfere with data collection. Based on the findings of the pilot study, certain modifications of the tools were done, and hence the pilot children were not included in the main study sample. The pilot study took ten days . 


\section{Field of work:}

The researcher assess children' knowledge and practice by collecting data regarding thalassemia and chelation therapy by using (tool I). It took approximately 15 to 20 minutes to fulfill the interview. The assessment was implemented two days per week during a period of 7 months from april 2015 to october 2015.

\section{(III) ADMINISTRATIVE DESIGN}

Official letters from the Faculty of Nursing, Port- Said University, were addressed to the General Director of the National Health Insurance hospital, and permission was obtained to conduct the study after explanation of the study objectives and procedures.

\section{Ethical Consideration:}

The purpose and procedures of the study were explained clearly and simply to every child and his/her caregiver to obtain their informed assents and consents to participate in the study. This was done to gain their cooperation and decrease their level of anxiety. The researcher also informed them about their rights to refuse or withdraw at any time without giving reason and with no consequences on their care. They were assured that any information obtained would be confidential and used only for the purpose of the study. The study maneuvers could not harm the participants. Professional help and advice were provided as needed After obtaining the official permission to conduct the study, the studied children and were informed with the aim and nature of the study. It was emphasized that the participation is voluntary and confidential and anonymity of the subject was assured through coding of data.

\section{(IV) STATISTICAL DESIGN:}

The raw data were coded and transformed into coding sheets. The results were checked. Then, the data were entered using SPSS version 20.0 statistical software package. Output drafts were checked against the revised coded data, percentage and percentage distribution.

\section{Limitation of the Study:}

The different reactions of parents to child illness acted as psychological burden on the researcher when dealing with them. The main barriers faced by the researcher were the lack of children' motivation to participate and the overcrowded outpatient clinic. 
Additionally, most caregivers were in hurry and wanted to go home soon. Some caregivers refused to participate in the study even after ensuring the confidentiality

\section{RESULTS:}

Table (1): The study sample consisted of 50 children whose age ranged between 8 and 18 years, median 12.0 years, with slightly more females (56.0\%) as shown in Table 1 . The majority were firstborn children (82.0\%). Approximately one-third of the children left school (32.0\%), mostly at the primary level. Among those who continued in school, more than half were at the primary level of education (55.9\%). Overall, more than three-fourth of the children were able to read and write $(76.0 \%)$..

Table (2): As for parents, Table 2 shows that mother age ranged between 27 and 50 years, median 35.5 years, while fathers' age ranged between 33 and 55 years, median 41.0 years. Most mothers and fathers had basic/intermediate level of education. $50.0 \%$ and $60.0 \%$ respectively. The majority of the mothers were housewives (86.0\%) and of the fathers were employees $(82.0 \%)$.

Table (3): indicates that the majority of the parents were living together (86.0\%). Slightly more than a half of them were extended families (54.0\%), in rural residences (58.0\%), with insufficient income (56.0\%), and a crowding index $<2(54.0 \%)$

Table (4): indicates that the area of highest percentage of satisfactory knowledge about thalassemia among the children in the study sample was that of the cause of the disease $(100.0 \%)$. Conversely, the areas of complications and their causes had the lowest percentages of satisfactory knowledge, $2.0 \%$ and $8.0 \%$ respectively.

Table (5): As regards children's knowledge of the treatment of thalassemia, Table 4 demonstrates generally low percentages of satisfactory knowledge. This was most regarding the benefits of blood transfusion, of drugs, and of needed investigations, where none $(0.0 \%)$ of the children had satisfactory knowledge.

Table (6): illustrated, children's knowledge of desferal was very low. The percentages of satisfactory knowledge ranged between $0.0 \%$ for the side effects of the drug to $60.0 \%$ for its importance. 
In total, table (7): demonstrates that the area of lowest percentage of satisfactory knowledge among the children in the study sample was that of management (12.0\%).

Table 1: Socio-demographic characteristics of children in the study sample $(n=50)$

\begin{tabular}{|c|c|c|}
\hline & Frequency & Percent \\
\hline \multicolumn{3}{|l|}{ Child age: } \\
\hline$<12$ & 26 & 52.0 \\
\hline $12+$ & 24 & 48.0 \\
\hline Range & \multicolumn{2}{|c|}{$8.0-18.0$} \\
\hline Mean \pm SD & \multicolumn{2}{|c|}{$12.6 \pm 3.0$} \\
\hline Median & \multicolumn{2}{|c|}{12.0} \\
\hline \multicolumn{3}{|l|}{ Gender: } \\
\hline Male & 22 & 44.0 \\
\hline Female & 28 & 56.0 \\
\hline \multicolumn{3}{|l|}{ Birth order: } \\
\hline 1 & 41 & 82.0 \\
\hline $2+$ & 9 & 18.0 \\
\hline \multicolumn{3}{|l|}{ Education: } \\
\hline Left school & 16 & 32.0 \\
\hline Studying & 34 & 68.0 \\
\hline \multicolumn{3}{|l|}{ Left at level: } \\
\hline Primary & 14 & 87.5 \\
\hline Preparatory & 1 & 6.3 \\
\hline Secondary & 1 & 6.3 \\
\hline \multicolumn{3}{|l|}{ Studying at level: } \\
\hline Primary & 19 & 55.9 \\
\hline Preparatory & 6 & 17.5 \\
\hline Secondary & 9 & 26.5 \\
\hline Can read & 38 & 76.0 \\
\hline Can write & 38 & 76.0 \\
\hline
\end{tabular}


Table (2): Socio-demographic characteristics of parents of children in the study sample $(\mathrm{n}=50)$

\begin{tabular}{|c|c|c|}
\hline & Frequency & Percent \\
\hline \multicolumn{3}{|l|}{ Mother age: } \\
\hline$<35$ & 19 & 38.0 \\
\hline $35+$ & 31 & 62.0 \\
\hline Range & \multicolumn{2}{|c|}{$27.0-50.0$} \\
\hline Mean \pm SD & \multicolumn{2}{|c|}{$36.0 \pm 5.1$} \\
\hline Median & \multicolumn{2}{|c|}{35.5} \\
\hline \multicolumn{3}{|l|}{ Mother education: } \\
\hline Illiterate/ Read/write & 14 & 28.0 \\
\hline Basic/Intermediate & 25 & 50.0 \\
\hline University & 11 & 22.0 \\
\hline \multicolumn{3}{|l|}{ Mother job status: } \\
\hline Housewife & 43 & 86.0 \\
\hline Working & 7 & 14.0 \\
\hline \multicolumn{3}{|l|}{ Father age: } \\
\hline$<40$ & 18 & 36.0 \\
\hline $40+$ & 32 & 64.0 \\
\hline Range & \multicolumn{2}{|c|}{$33.0-55.0$} \\
\hline Mean \pm SD & \multicolumn{2}{|c|}{$41.8 \pm 5.8$} \\
\hline Median & \multicolumn{2}{|c|}{41.0} \\
\hline \multicolumn{3}{|l|}{ Father education: } \\
\hline Illiterate/ Read/write & 13 & 26.0 \\
\hline Basic/Intermediate & 30 & 60.0 \\
\hline University & 7 & 14.0 \\
\hline \multicolumn{3}{|l|}{ Father job: } \\
\hline Employee & 9 & 18.0 \\
\hline Worker & 41 & 82.0 \\
\hline
\end{tabular}


Table (3): Family characteristics of children in the study sample $(\mathrm{n}=50)$

\begin{tabular}{||l|c|c||}
\hline & Frequency & Percent \\
\hline Parents together: & 43 & 86.0 \\
Yes & 7 & 14.0 \\
\hline Fo (Divorced/separated/widow) & & \\
Nuclear & 23 & 46.0 \\
Extended & 27 & 54.0 \\
\hline Residence: & 21 & 42.0 \\
Urban & 29 & 58.0 \\
Rural & 28 & 56.0 \\
\hline Income: & 22 & 44.0 \\
Insufficient & 23 & 46.0 \\
Sufficient & 27.0 \\
\hline Crowding index: & 23 & 54.0 \\
$<2$ & & \\
$2+$ & & \\
\hline
\end{tabular}

Table (4): knowledge of studied children about thalassemia

\begin{tabular}{|l|c|c||}
\hline \hline knowledge of studied children about thalassemia & $(\mathrm{n}=50)$ & $\%$ \\
\hline Nature & 22 & 44.0 \\
\hline Prevalence & 16 & 32.0 \\
\hline Causes & 50 & 100.0 \\
\hline Symptoms & 8 & 16.0 \\
\hline Complications & 1 & 2.0 \\
\hline Causes of Complications & 4 & 8.0 \\
\hline
\end{tabular}


Table (5): Knowledge of treatment of thalassemia among children in the study sample $(\mathrm{n}=50)$

\begin{tabular}{||l|c|c||}
\hline \multicolumn{1}{|c|}{ Correct Knowledge About } & $(\mathrm{n}=50)$ & $\%$ \\
\hline Types & 32 & 64.0 \\
\hline Benefits of blood transfusion (BT) & 0 & 0.0 \\
\hline Problems of repeated BT & 2 & 4.0 \\
\hline Iron accumulation & 8 & 16.0 \\
\hline High iron food & 38 & 76.0 \\
\hline Food increasing iron absorption & 42 & 84.0 \\
\hline Drugs ridding body of excess iron & 30 & 60.0 \\
\hline Benefits of these drugs & 0 & 0.0 \\
\hline Use of these drugs & 36 & 72.0 \\
\hline Side effects of these drugs: & 2 & 4.0 \\
Needed investigations & 0 & 0.0 \\
\hline \hline
\end{tabular}

Table (6): Knowledge of desferal in treatment of thalassemia among children in the study sample $(\mathrm{n}=50)$

\begin{tabular}{||l|c|c||}
\hline \multicolumn{1}{|c|}{$\begin{array}{c}\text { Correct Knowledge } \\
\text { About desferal }\end{array}$} & $(\mathrm{n}=50)$ & $\%$ \\
\hline Importance & 30 & 60.0 \\
\hline Weekly dose & 19 & 38.0 \\
\hline Side effects & 0 & 0.0 \\
\hline Management of side effects: & 22 & 44.0 \\
\hline Inflammation (abdomen) & 21 & 42.0 \\
\hline Abdominal abscess & 14 & 28.0 \\
\hline Disturbed vision/ hearing & 14 & 28.0 \\
\hline Allergy & 16 & 32.0 \\
\hline When to stop & 4 & 8.0 \\
\hline Symptoms that need stoppings & & \\
\hline
\end{tabular}


Table (7): Total knowledge among children in the study sample $(\mathrm{n}=50)$

\begin{tabular}{|l|c|c|}
\hline \multicolumn{1}{|c|}{$\begin{array}{c}\text { Satisfactory Knowledge } \\
\text { About }\end{array}$} & $(\mathrm{n}=50)$ & $\%$ \\
\hline Thalassemia & 13 & 26.0 \\
\hline Management & 6 & 12.0 \\
\hline Desferal & 13 & 26.0 \\
\hline
\end{tabular}

\section{DISCUSSION:}

Thalassemia is a major inherited public health problem in Mediterranean people (Carman \& Kyle, 2015; Satta et al., 2017). Previously a rapidly fatal disease in early childhood, it is now a chronic disease with better life expectancy (Origa, 2017). There are several reasons for inadequate chelation such as lack of children knowledge about chelation therapy (Arif et al., 2008).

The study sample included 50 children with age ranging between 8 and 18 years, slightly more females, and a majority of firstborns. As regards disease characteristics, the median age at diagnosis was 1.0 year, with slightly less than a half of them diagnosed before oneyear age. In congruence with this, two different studies on Pakistani (Ammad et al., 2011) and Iranian (Khani et al., 2012).

The lack of knowledge and awareness about available iron chelating agents, their side effects, and the means of managing these side effects is an important problem that interferes with compliance with iron chelation therapy. This, lack of knowledge problem, was mirrored in the results of the present study where almost all the studied children had unsatisfactory total knowledge score about chelation therapy and iron chelating agents before implementation of health instructions. This could also be the most important factor underlying the high rates of complications found among them.

The present study attempted to improve thalassemic children's knowledge about their disease. The pretest showed that all of them knew the cause of the disease, which is quite expected since this is the first information provided to them upon diagnosis. Conversely, they had deficient knowledge about the nature and definition of thalassemia, its 
symptoms, complications and related causes at the pretest. This is expected given the complexity of the disease. Moreover, the lack of knowledge about complications could be attributed to denial and avoidance to talk about ominous events that could occur to them. In addition, most health professionals in the clinics do not usually explain the meaning of the disease and focus on treatment and/or prevention. Another possible factor for the deficient knowledge in the present study is the shortage of nursing staff number in the setting, with associated lack explanation about the disease and its care aspects.

In congruence with these present study findings, a similar deficient knowledge about Thalassemia definition was shown by Mohamed (2013) among studied children in Zagazig University. Similarly, Mostafa \& Abd Elaziz (2014) mentioned that about two thirds of studied children in Zagazig University Hospitals were unable to define Thalassemia correctly. As regards the deficient knowledge of symptoms, Hassan (2010) in a study in Cairo University reported that the studied thalassemic children had similarly poor knowledge.

Concerning the lack of knowledge about complications, the current study findings agree with those of Yang et al. (2005) whose study revealed that the worst knowledge score was the knowledge of complications. Concerning children's knowledge of the treatment of Mediterranean fever, the present study findings demonstrated generally deficient knowledge before the intervention. This was most evident in the knowledge of the benefits of blood transfusion, of drugs, and of needed investigations. This could be due to the young age of most of the children, so that most of them were unable to assimilate such information. Such knowledge is important for the thalassemic children in order to be cautious about possible treatment side effects such as transmission of infections agents or the development of iron overload. In this regard, Gharagozloo et al (2009); Yaish (2010) stressed that the children with thalassemia major are prone to develop infection more than normal children do, regardless of the transfusion status.

Meanwhile, a large percentage of the children in the current study had satisfactory knowledge of the food rich in iron as well as the food items that increase the absorption of iron from the gut before implementation of the intervention 
Such knowledge is important in protecting these children form the risk of accumulation of iron in their bodies. Their related high knowledge is not surprising since it usually becomes part of their daily life routines to avoid these foods. In congruence with this, Upadyay \& Chatterjee (2009) reported that 95\% of the studied patients knew they should avoid foods rich in iron. Similarly, in a study in Taiwan, Lee et al. (2008) found that three quarters of the studied thalassemic patients reported that the diet for Thalassemia patients should be low in iron.

The present study has also assessed children's knowledge of desferal. The percentages of children with satisfactory knowledge were very low before the intervention. This was particularly evident regarding the side effects of the drug, which was not known by any of them, as well as the symptoms that need stopping the drug. The findings are alarming since all children are using this medication, and almost a half of them have their own pumps and can manage it. This could be attributed to deficient patient education, as some physicians may have a false belief that if the child knows the possible side effects of the drug, he/she will be afraid of taking it and consequently will not comply with it. Moreover, the pamphlets of all iron chelating agents were written in English language, so that it cannot be read or understand by most of the patients. Therefore, it is of major importance that they should know about the side effects as well as the warning signs that should lead to stopping the drug.

In agreement with these present study findings, a similar deficient knowledge of side effects of desferal was found by $\boldsymbol{E l - A w a n y ~ ( 2 0 0 2 ) ~ i n ~ a ~ s t u d y ~ i n ~ A i n ~ S h a m s ~ U n i v e r s i t y . ~}$ On the same line, Mohamed (2013) found that nearly three quarters of the studied adolescents in Zagazig University did not know what to do to avoid desferal inflammation before implementation of health instructions.

Nonetheless, approximately two-thirds of the children in the present study had satisfactory knowledge about the importance of disferal and its utility in the treatment of thalassemia. This could be due to the instructions provided by their caregivers, whether formal or informal, while administering it to them. The finding is in agreement with the results reported by Mohamed (2013) who, in a study of the importance of iron chelating agents in Zagazig University, found that more than four-fifth of the children knew that iron chelating agents decrease iron overload. On the same line, Lee et al. (2008) reported 
that the majority of studied patients in Taiwan stated that the reason for taking iron chelators was to get rid of excess iron and to avoid iron sedimentation

\section{CONCLUSION:}

Based on the findings of the present study, it was concluded that major deficiencies in knowledge of children with thalassemia and undergoing chelation therapy

\section{RECOMMENDATIONS:}

Based on the findings of the present study, the following recommendations are to be considered: Health teaching and counseling programs should be provided for children with thalassemia and undergoing chelation therapy to decrease burden on them and make them the focus of the health care team through updated posters and brochures that help improve their knowledge about thalassemia and chelation therapy.

\section{REFERENCES:}

Ammad S.A., Mubeen S.M., Shah S.F., and Mansour S. (2011): Parents opinion of Quality of life (QOL) in Pakistan thalassemic children JPMA; 61(5):470-473

Arif F., Fayyaz J., and Hamid A. (2008): Awareness among parent children with Thalassemia major, J. Pak. Med Association; 58(11): 621 - 624

Carman S., and Kyle T. (2015): Nursing care of children with hematologic disorders In: Essential of pediatric nursing, 3rd ed., Philadelphia: Walters Kluwer Health, Lippincott Williams\& Wilkins Co., pp. 926

Carman S., and Kyle T. (2015): Nursing care of children with hematologic disorders In: Essential of pediatric nursing, 3rd ed., Philadelphia: Walters Kluwer Health, Lippincott Williams\& Wilkins Co., pp. 926

Cooley Anemia Foundation .(2009): What is thalassemia ?Retrived January 23, 2009, from Http://www.thalassemia.org.

El-Awany T.A. (2002): Nutritional program for children with Beta-thalassemia major and their mothers. Unpublished Doctoral Dissertation, Faculty of Nursing, Ain Shams University, Cairo 
El-Beshlawy A. (2008): thalassemic prevalence and status in Egypt. Pediatric research, $40(5), 760$.

Gharagozloo M., Bagherpour B., and Tahanian M. (2009): premature senescence of T Lymphocytes form patient with $\beta$-Thalassemia Major. Immunol Lett.; 122(1): 84 - 8 .

Hassan E.A. (2010): Impact of educational program on adherence of thalassemia children with iron chelation therapy in hematology clinics. Published Doctoral Dissertation, Faculty of Nursing, Cairo University, Cairo

Khani H., Majdi M.R., Marzabadi E.A., Montazeri A., Ghorbani A., and Ramezani M. (2012): Quality of life of Iranian B-thalassemia Major patients living on the southern coast of the Caspian Sea. Eastern Mediterranean Health Journa;18(4):539-545

Kline N. (2010): Alterations of hematological function in children. pathophysiology: The biologic basis for disease in adults and children 6th ed., Elsevier com. Mosby; P. 999.

Lee Y.L., Lin D.T., and Tsai S.F. (2008): Disease knowledge and treatment adherence among patients with thalassemia major and their mothers in Taiwan. Journal of Clinical Nursing; 18(1):529-538

McCance K. and Grey T. (2010): Altered cellular and tissue biology, 6th ed., Mosby com; P. 952

Mohamed E.M. (2013): Impact of health instruction on improving knowledge and practices of thalassemic adolescents at Zagazig university hospital. Published, Master Thesis, Faculty of Nursing, Zagazig University, Zagazig

Mostafa S., and Abd Elaziz M. (2014): Factors affecting compliance plan of thalassemic children and their mothers in Outpatient Clinic at Zagazig University Hospitals, p. 49

Origa R. (2017): $\quad \beta$-Thalassemia. Genet Med.;19(6):609-619. doi: 10.1038/gim.2016.173. Epub 2016 Nov 3

Satta S., Paglietti M.E., Sollaino M.C., Barella S., Moi P., Desogus M.F., Demartis F.R., Manunza L., and Origa R. (2017): Changes in $\mathrm{HbA} 2$ and $\mathrm{HbF}$ in alpha thalassemia carriers with KLF1 mutation. Blood Cells Mol Dis.;64:30-32. doi: 10.1016/j.bcmd.2017.03.007. Epub 2017 Mar 18 
Wilson D. and Hockenberry M. (2011): Wong's Nursing Care of Infants and Children, 9th ed., Philadelphia Mosby; P. 1439.

Yaish H.M. (2010): Pediatric Thalassemia treatment and management, max j. Coppes HD Phd. Available from: Http://emedicine.medscape.com / article / 958850 - diagnosis

Yaish H.M. (2013): Pediatric Thalassemia. Available at: Http:// emedicine.medscape.com/ article/958850 - overview \# show all. Accessed at March 19, 2013.

Yang H.C., Chen Y.C., Mao H.C., and Lin K.H. (2005): Social support and self care behavior in adolescents with beta-thalassemia major. Metabolism; 54(1):15-23.

Zorac J., Alpern E., Brown L., Loomes K., Marino B., Mollen C. and Raffini J. (2013): Clinical handbook of pediatrics, 5th ed., Philadelphia: Lippincott Williams \& Wilkins; P. 431.

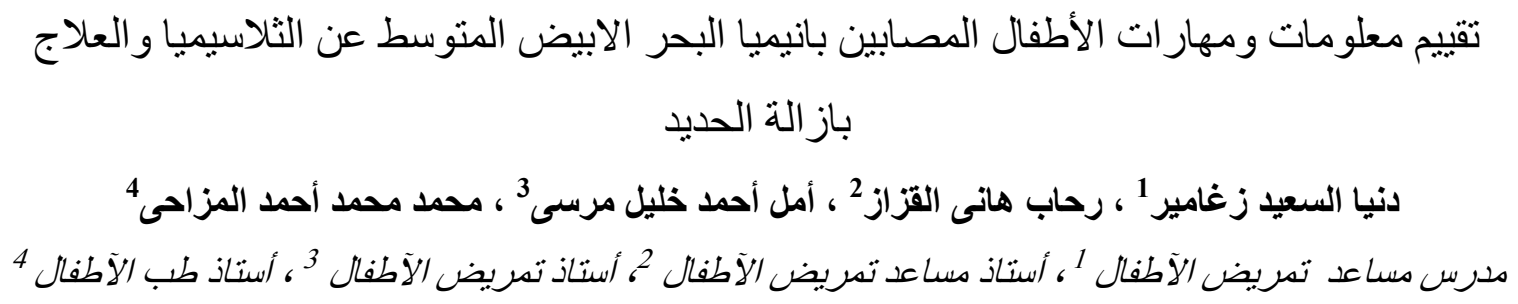

\section{الخلاصة}

تهدف هذه الدراسة الوصفية إلي تقييم معلومات ومهارات الاطفال المصابين بانيميا البحر الابيض المتوسط عن الثلاسيميا والعلاج باز الة الحديد وقد أجريت هذه الدراسة في مستشفى التامين الصحى بدمياط في العيادات الخارجية وشملت العينة 50 من الاطفال لمصابين بالثلاسيميا أثناء فترة جمع البيانات لمدة 12 شهر وذلك من ابريل 2015- ابريل 2016. كما استخدمت اداتين لجمع البيانات: الأداة الأولى وهي استمارة استبيان مصممة بواسطة الباحث وتحتوى على البيانات الثخصية و الاجتماعية للطفل والأسرة ، ،اما الأداه الثانيه فهي تشمل تقييم معلومات ومهار ات الاطفال عن الثلاسيميا و العلاج باز الة الحديد ولقد أوضحت الدراسة ان 12\% فقط من الاطفال لديهن معلومات كافية مرتبطة بالثناسيميا وان 12\%، 26\% منهن فقط لديهن مهار ات مرتبطة بعلاج الثناسيميا والعلاج باز الة الحديد ـ لذا فقد أوصت الدراسة لأقامة برامج تعليمية بصفة مستمرة لهؤلاء الاطفال وتكرار هذا البحث على عينة كبيرة و في أماكن مختلفة في مصر وجعل أمهات الأطفال المصابين بالثثلاسيميا محور اهتمام فريق الرعاية الصحية من خلال النشرات المحدثة والملصقات و الكتيبات التي تساعد علي تحسين معلو ماتهن ومن ثم تحسين الحالة الصحية لأطفالهن. الكلمات المرشدة: معلومات ومهارات الاطفال ـ الثلاسيميا ـ العلاج باز الة الحديد_أنيميا البحر الأبيض المتوسط 